\title{
Clinico pathological study of goitre among women in a tertiary government hospital
}

\author{
Naik M. R. ${ }^{1}$, Vudumula V. L. ${ }^{2 *}$ \\ DOI: https://doi.org/10.17511/ijphr.2015.i1.05 \\ 1 Naik M. R., Professor, Department of General Surgery, Government Medical College, Ananthapuramu, Andhra Pradesh, India. \\ 2* Vudumula V. L., Assistant Professor, Department of General Surgery, Government Medical College, Ananthapuramu, Andhra Pradesh, \\ India. \\ Introduction: Diseases of the thyroid gland are one of the commonest endocrine disorders in India \\ as well as in the world. It is estimated that nearly 42 million people in India suffer from thyroid \\ diseases. They may be diffuse or nodular, benign or malignant, euthyroid or hyperthyroid in status. \\ The spectrum of thyroid diseases includes simple goitre, thyroiditis, adenoma, carcinoma, \\ multinodular goiter, hypo or hperthyroidism and Graves' disease. It is postulated that the incidence \\ of thyroid nodule increases with age, in women, in people with iodine deficiency, and after radiation \\ exposure. Materials \& Methods: Study done in Government General Hospital Ananthapuramu. \\ Cross sectional descriptive study. Study subjects were included based on inclusion criteria who have \\ given consent for the study. Results: A total of 35 women were enrolled for this study. Mean age of \\ the study subjects is 36.51 years. A report suggests a prevalence of $2-6 \%$ with palpation, $19-35 \%$ \\ with ultrasound, and $8-65 \%$ in autopsy data while a prevalence of $4-7 \%$ has been estimated in \\ another.. Conclusion: The prevalence of goitre is different according to the geographical region, age \\ and sex. Majority of the study subjects had Swelling of neck. Among Biopsy reports majority were \\ diagnosed as Multy nodular goiter. We recommend further detailed study in this area to explore \\ further details for the benefit og general population.
}

Keywords: Hypothyroidism, Ananthapuramu, Thyroid, Goitre

Corresponding Author

Vudumula V. L., Assistant Professor, Department of General Surgery, Government Medical College, Ananthapuramu, Andhra Pradesh, India.
How to Cite this Article

To Browse

Naik MR, Vudumula VL. Clinico pathological study of goitre among women in a tertiary government hospital. Public Health Rev Int J Public Health Res. 2015;2(1):25-29.

Available From

https://publichealth.medresearch.in/index.php/ijphr/ article/view/13

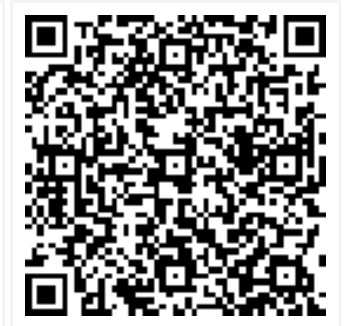

Manuscript Received 2015-03-08

Conflict of Interest No

Review Round 1
2015-03-13
Funding
Nil

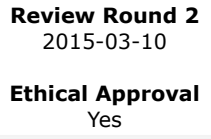

Accepted 2015-03-30

Plagiarism $X$-checker $7 \%$

Note 


\section{Introduction}

Diseases of the thyroid gland are one of the commonest endocrine disorders in India as well as in the world. It is estimated that nearly 42 million people in India suffer from thyroid diseases. [1] They may be diffuse or nodular, benign or malignant, euthyroid or hyperthyroid in status. The spectrum of thyroid diseases includes simple goitre, thyroiditis, adenoma, carcinoma, multinodular goiter, hypo or hperthyroidism and Graves' disease. It is postulated that the incidence of thyroid nodule increases with age, in women, in people with iodine deficiency, and after radiation exposure. A report suggests a prevalence of $2-6 \%$ with palpation, 19$35 \%$ with ultrasound, and $8-65 \%$ in autopsy data [ 2 ] while a prevalence of $4-7 \%$ has been estimated in another [3 ] The prevalence of goitre is different according to the geographical region, age and sex. [4] Thyroid nodules are common clinical findings and have a reported prevalence of $4 \%$ to $7 \%$ in the adult population. Thyroid swellings are four times more common in females. FNAC has now supplanted most of the other tests for pre-operative evaluation of thyroid nodules. Thyroid surgeries are most common surgeries especially in the female population. Nearly more than $40 \%$ of the postoperative thyroid surgery patients experience significant postoperative pain with pain score above 4 reflecting inadequate analgesia considered independent risk factor. The present study was undertaken to study clinical pathology of goitre among women in a tertiary government hospital.

\section{Materials \& Methods}

Study done in Government General Hospital Ananthapuramu. Cross sectional descriptive study. Study subjects were included based on inclusion criteria who have given consent for the study. The study period was from January to july 2014. A total of 35 women mean age of 36.51 years were enrolled for this study after obtaining free, written, voluntary informed consent. The study was approved by institutional ethical committee. Participants selectection was done by convienient sampling and inclusion and exclusion criteria are as follows.

Inclusion criteria: Willing, women diagnosed with goiter.

Exclusion criteria: Unwilling, severe thyroid disorders.
Data analysis: Data was analyzed by SPSS 20.0. Data was expressed in frequency and percentage.

\section{Results}

Results are presented in table no 1 to table no 4 . Table no 1 presents Descriptive data on age of study subjects. Table 2 presents Relation of FNAC and age group. Table 3 presents Biopsy and age group. Table no 4 presents Table 4: Chief complaints among study subjects.

Table 1: Descriptive data on age of study subjects

\begin{tabular}{|l|l|}
\hline \multicolumn{1}{|c|}{ Mean } & \multicolumn{1}{c|}{36.51} \\
\hline Std. Error of Mean & 2.403 \\
\hline Median & 32.00 \\
\hline Mode & 20 \\
\hline Std. Deviation & 14.218 \\
\hline Variance & 202.139 \\
\hline Range & 45 \\
\hline Minimum & 20 \\
\hline Maximum & 65 \\
\hline \multicolumn{1}{|c|}{ Sum } & \multicolumn{1}{|c|}{$\mathbf{2 7 8}$} \\
\hline
\end{tabular}

Mean age of the participants is 36.51

Table : 2 Relation of FNAC and age group

\begin{tabular}{|c|c|c|c|c|c|}
\hline \multicolumn{2}{|l|}{ FNAC } & \multicolumn{3}{|c|}{ Age group } & \multirow[t]{2}{*}{ Total } \\
\hline & & $20-40$ & $40-60$ & $>60$ & \\
\hline \multirow[t]{2}{*}{ Adenomatous goiter } & Count & 0 & 1 & 0 & 1 \\
\hline & $\%$ of Total & $.0 \%$ & $2.9 \%$ & $.0 \%$ & $2.9 \%$ \\
\hline \multirow{2}{*}{$\begin{array}{l}\text { Adenomatous goiter } \\
\text { microcystic degeneration }\end{array}$} & Count & 0 & 1 & 0 & 1 \\
\hline & $\%$ of Total & $.0 \%$ & $2.9 \%$ & $.0 \%$ & $2.9 \%$ \\
\hline \multirow[t]{2}{*}{ Colloid goiter } & Count & 7 & 5 & 1 & 13 \\
\hline & $\%$ of Total & $20.0 \%$ & $14.3 \%$ & $2.9 \%$ & $37.1 \%$ \\
\hline \multirow[t]{2}{*}{ Nodular colloid goiter } & Count & 3 & 2 & 1 & 6 \\
\hline & $\%$ of Total & $8.6 \%$ & $5.7 \%$ & $2.9 \%$ & $17.1 \%$ \\
\hline \multirow{2}{*}{$\begin{array}{l}\text { Nodular colloid goiter } \\
\text { with cystic degeneration }\end{array}$} & Count & 2 & 0 & 0 & 2 \\
\hline & $\%$ of Total & $5.7 \%$ & $.0 \%$ & $.0 \%$ & $5.7 \%$ \\
\hline \multirow{2}{*}{$\begin{array}{l}\text { Nodular colloid goiter } \\
\text { with hemarrhage with cystic } \\
\text { degenaration }\end{array}$} & Count & 1 & 0 & 0 & 1 \\
\hline & $\%$ of Total & $2.9 \%$ & $.0 \%$ & $.0 \%$ & $2.9 \%$ \\
\hline \multirow[t]{2}{*}{ Nodular goiter } & Count & 3 & 1 & 0 & 4 \\
\hline & $\%$ of Total & $8.6 \%$ & $2.9 \%$ & $.0 \%$ & $11.4 \%$ \\
\hline \multirow{2}{*}{$\begin{array}{l}\text { Nodular goiter with cystic } \\
\text { degeneration }\end{array}$} & Count & 1 & 0 & 0 & 1 \\
\hline & $\%$ of Total & $2.9 \%$ & $.0 \%$ & $.0 \%$ & $2.9 \%$ \\
\hline \multirow[t]{2}{*}{ follicular adenoma } & Count & 5 & 1 & 0 & 6 \\
\hline & $\%$ of Total & $14.3 \%$ & $2.9 \%$ & $.0 \%$ & $17.1 \%$ \\
\hline \multicolumn{2}{|l|}{ Count } & 22 & 11 & 2 & 35 \\
\hline
\end{tabular}


Table 3: Biopsy and age group

\begin{tabular}{|c|c|c|c|c|c|}
\hline \multicolumn{2}{|l|}{ Biopsy } & \multicolumn{3}{|c|}{ Age group } & \multirow[t]{2}{*}{ Tota } \\
\hline & & $20-40$ & $20-40$ & $20-40$ & \\
\hline \multirow[t]{2}{*}{ Adenoma thyroid } & Count & 1 & 0 & 0 & 1 \\
\hline & $\%$ of Total & $2.9 \%$ & $.0 \%$ & $.0 \%$ & $2.9 \%$ \\
\hline \multirow[t]{2}{*}{ Adenomatous goiter } & Count & 3 & 2 & 0 & 5 \\
\hline & $\%$ of Total & $8.6 \%$ & $5.7 \%$ & $.0 \%$ & $14.3 \%$ \\
\hline \multirow[t]{2}{*}{ Colloid goiter } & Count & 0 & 1 & 2 & 3 \\
\hline & $\%$ of Total & $.0 \%$ & $2.9 \%$ & $5.7 \%$ & $8.6 \%$ \\
\hline \multirow{2}{*}{$\begin{array}{l}\text { Colloid goiter with cystic } \\
\text { changes }\end{array}$} & Count & 1 & 0 & 0 & 1 \\
\hline & $\%$ of Total & $2.9 \%$ & $.0 \%$ & $.0 \%$ & $2.9 \%$ \\
\hline \multirow[t]{2}{*}{ Hashimotos thyroiditis } & Count & 1 & 1 & 0 & 2 \\
\hline & $\%$ of Total & $2.9 \%$ & $2.9 \%$ & $.0 \%$ & $5.7 \%$ \\
\hline \multirow[t]{2}{*}{ Micro follicular adenoma } & Count & 1 & 2 & 0 & 3 \\
\hline & $\%$ of Total & $2.9 \%$ & $5.7 \%$ & $.0 \%$ & $8.6 \%$ \\
\hline \multirow[t]{2}{*}{ Mixed folliculal adenoma } & Count & 5 & 0 & 0 & 5 \\
\hline & $\%$ of Total & $14.3 \%$ & $.0 \%$ & $.0 \%$ & $14.3 \%$ \\
\hline \multirow[t]{2}{*}{ Multy nodular goiter } & Count & 4 & 1 & 0 & 5 \\
\hline & $\%$ of Total & $11.4 \%$ & $2.9 \%$ & $.0 \%$ & $14.3 \%$ \\
\hline \multirow{2}{*}{$\begin{array}{l}\text { Multy nodular goiter with } \\
\text { fibrosis }\end{array}$} & Count & 1 & 0 & 0 & 1 \\
\hline & $\%$ of Total & $2.9 \%$ & $.0 \%$ & $.0 \%$ & $2.9 \%$ \\
\hline \multirow{2}{*}{$\begin{array}{l}\text { Multy nodular goiter with } \\
\text { hashimotos thyroiditis }\end{array}$} & Count & 1 & 0 & 0 & 1 \\
\hline & $\%$ of Total & $2.9 \%$ & $.0 \%$ & $.0 \%$ & $2.9 \%$ \\
\hline \multirow[t]{2}{*}{ Nodular goiter } & Count & 2 & 2 & 0 & 4 \\
\hline & $\%$ of Total & $5.7 \%$ & $5.7 \%$ & $.0 \%$ & $11.4 \%$ \\
\hline \multirow{2}{*}{$\begin{array}{l}\text { Nodular goiter with } \\
\text { Degenarative changes }\end{array}$} & Count & 0 & 1 & 0 & 1 \\
\hline & $\%$ of Total & $.0 \%$ & $2.9 \%$ & $.0 \%$ & $2.9 \%$ \\
\hline \multirow{2}{*}{$\begin{array}{l}\text { Nodular goiter with cystic } \\
\text { changes }\end{array}$} & Count & 1 & 0 & 0 & 1 \\
\hline & $\%$ of Total & $2.9 \%$ & $.0 \%$ & $.0 \%$ & $2.9 \%$ \\
\hline \multirow[t]{2}{*}{ follicular adenoma } & Count & 3 & 0 & 0 & 3 \\
\hline & $\%$ of Total & $8.6 \%$ & $.0 \%$ & $.0 \%$ & $8.6 \%$ \\
\hline \multirow{2}{*}{$\begin{array}{l}\text { multy nodular goiter with } \\
\text { secondary haemarrhage,no } \\
\text { malignancy }\end{array}$} & Count & 0 & 1 & 0 & 1 \\
\hline & $\%$ of Total & $.0 \%$ & $2.9 \%$ & $.0 \%$ & $2.9 \%$ \\
\hline \multicolumn{2}{|l|}{ Count } & 22 & 11 & 2 & 35 \\
\hline \multicolumn{2}{|l|}{$\%$ of Total } & $62.9 \%$ & $31.4 \%$ & $5.7 \%$ & $100.0 \%$ \\
\hline
\end{tabular}

Table 4: Chief complaints among study subjects

\begin{tabular}{|l|l|l|l|l|l|}
\hline \multicolumn{2}{|c|}{ Complants } & \multicolumn{3}{c|}{ Age group } & \multirow{2}{*}{ Total } \\
\cline { 2 - 5 } \multicolumn{2}{|c|}{} & $20-40$ & $20-40$ & $20-40$ & \\
\hline \multirow{3}{*}{ Swelling neck } & Count & 18 & 10 & 2 & 30 \\
\cline { 2 - 6 } & $\%$ of Total & $51.4 \%$ & $25.7 \%$ & $5.7 \%$ & $82.9 \%$ \\
\hline \multirow{3}{*}{ Difficulty to swallow } & Count & 4 & 1 & 0 & 5 \\
\cline { 2 - 5 } & $\%$ of Total & $11.4 \%$ & $2.9 \%$ & $.0 \%$ & $14.3 \%$ \\
\hline Count & 22 & 11 & 2 & 35 \\
\hline$\%$ of Total & $62.9 \%$ & $31.4 \%$ & $5.7 \%$ & $100.0 \%$ \\
\hline
\end{tabular}

\section{Discussion}

India has the world's largest goitre belt in the subHimalayan region [5].
It has been estimated that $12 \%$ of adult population in India have a palpable goitre. [6] The patterns of thyroid diseases observed in the current report are comparable with the available world literature. In the study conducted by Handa et al., the incidence of goitres among thyroid nodules was $57.6 \%$, followed by thyroiditis (27.4\%), adenomatous goitre $(2.3 \%)$, follicular/hurthle cell neoplasm (1.4\%) and malignant tumors $(3.9 \%)$, of which papillary carcinoma was the commonest. [5,7] Another Indian study conducted by Andaleeb et al., in 2002 showed $54.7 \%$ of multinodular goitre and $27.6 \%$ of follicular lesions. [8].

Bandela et al.[9] from Andhra Pradesh reported $10 \%$ prevalence of $\mathrm{SCH}$. Gayathri et al.[10] reported $2.8 \%$ prevalence of Sub clinical Hypothyroidism. Possible reason for such variability could be the different upper limit cut-offs used for $\mathrm{TSH}$. The patients were between 17 to 90 years of age with a mean age of 41.49 years.

These findings correlate with studies condu cted by Chowdary et al , Hanumanthappa, who suggested occurrence of multinodular goiter in 2 nd and $3 \mathrm{rd}$ decade of life. Our study findings are similar to the findings of Goellner et al, Altavilla et al and Manderkar et al. It was reported that most of the cases one can diagnose number of nodules clinically.

However ultrasonography has an important role in detecting actual number of nodules. This information is very essential for further investigations and necessary management. In 11 patients who have clinically solitary thyroid nodule turned out to be multinodular on USG. Fine needle aspiration cytology is the most important investigation for multinodular goiter.

Pre operative evaluation with ultrasound and FNAC can minimize the extent of surgery to be performed. Most of the times multinodular goiter turned out to be a benign pathology. Histopathological examination of the resected specimen proved useful to exclude malignancy.

\section{Conclusion}

The prevalence of goitre is different according to the geographical region, age and sex. Majority of the study subjects had Swelling of neck. Among Biopsy reports majority were diagnosed as Multy nodular goiter. We recommend further detailed study in this area to explore further details for the benefit og general population. 


\section{Reference}

01. Unnikrishnan AG, Menon UV. Thyroid disorders in India- An epidemiological perspective. Indian J Endocr Metab. 2011;15;78-81.

[Crossref]

02. Dean DS, Gharib H. Epidemiology of thyroid nodules. Best Pract Res Clin Endocrinol Metab. 2008;22;901-11.

[Crossref]

03. Mangesh Ram Padmawar, Kiran Kher, Anupam Kakade. Clinicopathological study of Multinodular goiter at AVBRH. International Journal of Biomedical And Advance Research. 2014; 5(1)10-13.

[Crossref]

04. Lamfon HA. Thyroid Disorders in Makkah, Saudi Arabia. Ozean J Appl Sci. 2008;1;55-8.

[Crossref]

05. Handa U, Garg S, Mohan H, Nagarkar N. Role of fine needle aspiration cytology in diagnosis and management of thyroid lesions- A study on 434 patients. J Cytol. 2008;25;13-7.

[Crossref]

06. Menon UV, Sundaram KR, Unnikrishnan AG, Jayakumar RV, Nair V, Kumar H. High prevalence of undetected thyroid disorders in an iodine sufficient adult south Indian population. J Indian Med Assoc. 2009;107;72-7.

[Crossref]

07. Sengupta S, Tuli IP, Baruah B, Kesari SP, Ilapakurty B, Gupta A. Spectrum of goitrous lesions in patients at a tertiary care center of Sikkim. Sahel Med J. 2014;17;112-6.

[Crossref]

08. Abrari, Ahmad SS, Bakshi V. Cytology in the otorhinolaryngologists domain- A study of 150 cases emphasizing diagnostic utility and pitfalls. Indian J Otolaryngol Head Neck Surg. 2002;54;107-10.

[Crossref]

09. Gayathri R, Lavanya S, Raghavan K. Subclinical hypothyroidism and autoimmune thyroiditis in pregnancy- A study in south Indian subjects. J Assoc Physicians India. 2009;57;691-3.

[Crossref]
10. Unnikrishnan AG, Kalra S, Sahay RK, Bantwal G, John M, Tewari N. Prevalence of hypothyroidism in adults- An epidemiological study in eight cities of India. Indian $\mathrm{J}$ Endocrinol Metab. 2013;17;647-5.

[Crossref] 